\title{
Indicator of Severe Violations Against Obligation and Prohibition of Notary Under the Notary Public Law
}

\author{
Lale Alifa Wining Sari ${ }^{1} \quad$ Salim HS$^{2} \quad$ Muhaimin $^{2}$ \\ 1.Graduate Program Student in Notary, Faculty of Law, Mataram University, Indonesia \\ 2.Lecturer of Faculty of Law, Mataram University, Indonesia
}

\begin{abstract}
Pursuant to Article 12 letter (d) The Notary Public Law, the notary can be dismissed in disrespect when committing a severe violation of the obligation and prohibition of office. Severe violations based on Article 12 of the letter $(d)$ is where the notary does not carry out obligations and violate the prohibition of the notary office. However, when associated with a notary obligation and prohibition set out in Article 16 and Article 17, The Notary Public Law does not constitute a clear arrangement of any notarized obligations and prohibitions which can be categorized as a severe violation so that the notary can be dismissed in disrespectful. The problem is how the indicator of severe violations of the obligation and prohibition of notary based on The Notary Public Law and how the implementation of legal sanctions on a notary who committed a severe violation of obligations and a notarized ban. This research aims to analyse the indicators of severe violations of legal obligations and prohibitions based on The Notary Public Law and the application of law sanctions against notaries that commit severe violations of the obligation and prohibition of notary ban. The method of this research is using a normative legal research methods because it examines the provisions of the legislation on the violation of severe violations of obligations and prohibitions. The approaches used are statutory approaches, conceptual approaches, and comparative approaches. The result of this research is first, the indicator of severe violations as referred to in Article 12 letter (d) The Notary Public Law and explanation is not fulfill the obligation and violate the prohibition of notary Office. The notary obligation which is stipulated in Article 16 of The Notary Public Law-P which if not fulfilled can be categorized as a severe violation among them is a notarized unacting, honest, careful, independent, immoral and safeguard the interests of the parties in conducting legal action, notary does not make a deed in the form of Deed Minuta and save it as part of a notary protocol, notarized not to attach letters and documents as well as fingerprints of the appearer in deed, notaries do not issue grosse deed, copies of the deed, or deed excerpts based on a deed, notary does not conceal any information obtained of the deed which is made, notary does not submit a list of deeds relating to the Will to the center of Wills in the Ministry of Government conducting Legal affairs within 5 (five) days of the first week of the following month, the notary is not reading the deed in front of the witness by being attended by at least 2 (two) witnesses, or 4 (four) special witnesses to the creation of the private deed and signed at that time also by the appearer, witnesses, and notary. A notarized prohibition as stipulated in Article 17 of The Notary Public Law-P that if violated may be categorized as a severe violation, i.e. a notary public, running a position outside of office, a notary as a civil servant, state officer, advocate, leader or officer of a state-owned enterprise, a regional-owned business entity or a private business entity, and concurrently serving as land deed official and/or class II auction office outside the notary public. Secondly, the application of legal sanctions that can be imposed against a notary who commits a serious violation of the obligation and a notarized ban among them are administrative sanctions, civil sanctions, notary code sanctions, or criminal sanctions.
\end{abstract}

Keywords: indicators, severe violations, the notary public law.

DOI: $10.7176 / \mathrm{JLPG} / 98-03$

Publication date:June 30th 2020

\section{INTRODUCTION}

Pursuant to Article 1 number (1) of Law No. 2 of 2014 concerning the amendment of Law number 30 of 2004 on the Department of Notary Public (hereinafter referred to as The Notary Public Law-P) stated that notary is the general Minister authorized to make authentic deed and has other authority as referred to in this law or under other laws. Notary has a highly repentant role in the traffic of law, especially in the field of civil law, because the notary is domiciled as the public minister, who has the authority to make authentic deeds and other authority. ${ }^{1}$

The arrangement of the authority, as well as the values that are owned by a notary so that the notary can perform their duties properly. That is why, although it is not always smooth and is not uncommon to have problems with, so that with or without accident, notary may commit violations which will eventually result in a sanction, which is where the sanction can be verbal strikes, written strikes, Advieraad dismissal, dismissal or disrespect.

Article 12 of the Law No. 30 of 2004 on the Department of Notarial ministry stated that the notary may be dismissed in disrespect of his position by the Minister on the proposal of the Central Supervisory Tribunal if:

\footnotetext{
${ }^{1}$ Salim H.S, Teknik Pembuatan Akta Satu Konsep Teoritis, Kewenangan Notaris, Bentuk dan Minuta Akta, PT. Raja Grafindo Persada, Jakarta, 2015, page. 33.
} 
a. Declared bankrupt based on a court ruling which has acquired the permanent legal force;

b. To be under continual remission of more than three consecutive years;

c. Conduct a degrading deed and the department of Notary Public;

d. Commit severe violations against the actual and prohibition of office.

Based on this, it is understood that if the notary is in a condition or do things as mentioned in Article 12, the Notary shall be unterminated. A notary as referred to in Article 12 reduce $(d)$ may be disrespectfully terminated in case of a severe violation of the actual and notarized ban. Severe violations of the obligation and the prohibition of notary pursuant to Article 12 reduce $(d)$ is not fulfilled and violates the Ministry of notary public.

Article 12 in this case is further explained in Article 16 and 17 of Law number 2 of 2014 concerning the amendment to Law number 30 of 2004 on the Department of Notary Public, which in Article 16 stated that in carrying out its office, the notary has actually:

a. Acting trustful, honest, equitable, independent, immoral, and safeguard the interests of the parties concerned in the act of law;

b. Create a deed in the form of a Deed Minuta and store it as part of the notary protocol;

c. Attach letters and documents as well as a fingerprint on the Minuta Deed;

d. Issuing the Grosse deed, a copy of the deed, or the deed based on deed Minuta;

e. Provide services in accordance with the provisions of this law, unless there is a reason to reject it;

f. Keep confidential everything about the deed, and any information obtained in order to make the deed in accordance with the oath/pledge, unless the law determines otherwise;

g. Bind the deed made in 1 (one) month into a book that contains no more than 50 (fifty) deed, and if the number of the deed could not be contained in a single book, the deed can be loaded into more than one book, and records the number of the deed Minuta, month, and year of its creation on the cover of each book;

h. Make a list of the deed of protest against unpaid or unreceived securities;

i. Make a list of deeds which are relating to wills in the order of the preparation time of the deed creation every month;

j. Submit a list of the deed as referred to in letter $(i)$ or nil list which is related with a will to the center of Wills in a ministry that conducts government affairs in the field of laws within 5 (five) days of the first week of the following month;

k. Records in the Repertorium the date of submission of wills at the end of each month;

1. Have a stamp that contains the symbol of the Republic of Indonesia and in the space that it is marked is written name, title, and place of position concerned;

$\mathrm{m}$. Read the deed in the presence of the roadblock by being attended by at least 2 (two) witnesses, or 4 (four) special witnesses to the creation of olographic testament, and signed at that time also by the appearer, witnesses, and notary; And

n. Receive a Notary candidate internship

In addition, in Article 17, The Notary Public Law declares that notary is prohibited:

a. Perform positions outside the territory of his office;

b. Leaving the territory of his office more than 7 (seven) consecutive working days for no valid reason;

c. Concurrently as civil servant;

d. Concurrently serving as state officials;

e. Concurrently serving as an advocate;

f. Concurrently serving as the leader or officer of a state-owned enterprise, a regional-owned enterprise or a private business entity;

g. Concurrently serving as Land Deed Official and/or Class II Auction Officials outside the position of notary public;

h. To be a Substitute Notary; Or

i. Do other works that contradict the religious norms, morality, or decency that could affect the honor and dignity of the notary office.

Pursuant to Article 16 and Article 17 of The Notary Public Law It can be noted that there are so many and complex obligations and restrictions that are owned by the notary in carrying out their duties. When connected with Article 12 of The Notary Public Law which governs the notary who can be dismissed disrespectfully due to the gross violations committed against the notarial obligations and prohibitions, this is of course a confusion even though it has been described in the explanation of Article 12 letter (D). This is because of the obligations and restrictions held by notaries that have been mentioned in Article 16 and Article 17 The Notary Public Law, not explained further so as to cause a legal blurring of obligations and a notarized ban which can be categorized as a gross offence resulting in a notary in question can be dismissed disrespectfully.

\section{RESEARCH METHOD}

This method of research is using normative legal research methods because it examines the provisions of the 
legislation on the violation of severe violations of obligations and prohibitions. The approaches used are statutory approaches, conceptual approaches, and comparative approaches.

\section{DISCUSSION}

1. The indicator of severe violations of the obligation and prohibition of notary based on The Notary Public Law. Serious violations of the obligation and the prohibition of a notary office are conceptualized that the is working on the criminal rules relating to the obligation and prohibition of notary Office. Notary obligation, such as acting trust, honest, careful, self-reliant, immutables, and safeguard the interests of the parties concerned in the act of law, and others. The prohibition of a notary office is conceptualized as matters not to be done by a notary in the conduct of its employees. The prohibition is like running a position outside of his office, etc. ${ }^{1}$

Severe violations constitute an act whereby the notary does not carry out the obligations and violates the restrictions set out in The Notary Public Law. Not implementing here means that the notary does not implement at all its obligations, and even do things that are forbidden in The Notary Public Law. ${ }^{2}$

In general there are several factors that are the reason why a notary is committing violations, namely: ${ }^{3}$

1. Interpretation in implementing the law

A notary in carrying out his duties and obligations is certainly based on the The Notary Public Law and notary Code of Ethics. The arrangement of The Notary Public Law and the notary Code of ethics is made solely for the notary to remain in the correct corridor, given that the notary public officials are authorized to make a deed based on the parties will. However, in this case, the provisions of The Notary Public Law, notary code, or other provisions relating to the notary make the notary itself has a different interpretation. This is because there are some provisions that do cause many interpretations so that sometimes between notary one and other notary has a different understanding or interpretation.

2. Ability of the notary self

The ability of a notary public to understand the provisions that have been governed either in The Notary Public Law, notary code of ethics, or other regulatory provisions is indispensable in carrying out their duties and obligations. In addition, the understanding of the parties wills and chronology of problems occurring between the parties is also indispensable, as this is closely related to the deed to be made by the notary. If the notary has understood the will and the problem between the parties, then the notary can make a deed in accordance with the will and problems that occur. It can be understood that the notary should also be able to make a legal opinion for any problems that come to it. That in the event of the inclusion of the parties to the deed, the notary must also be able to select and parse which information can be included, which is not only the will of the parties but also related to the problems that occur, and of course it should not contradict the provisions of legislation, morality, and public order.

Basically, when referring to the provisions concerning the obligations and restrictions held by the notary in carrying out the duties of office, all obligations and prohibitions owned by the notary can be categorized as a severe violation if indeed in whole based on the results of inspection of the Board of Trustees found that the notary does not carry out its obligations, moreover when doing what is forbidden as stipulated in The Notary Public Law. Because based on the explanation of Article 12 letter D, the violation itself is only given the definition of not carrying out obligations and violating the notary public. ${ }^{4}$

Inrespect of dismissal, in Article 10 of the Minister of Law and Human Rights regulation number 61 of 2016 on procedures for the enforcement of administrative sanctions on notary stated that unrespectful termination that can be imposed against a notary is done in the case of:

a. Notary public does not carry out obligations to be fulfilled by the notary until the temporary termination period has expired as intended in Article 7 paragraph (2); Or

b. The notary who is undergoing a period of temporary termination and it is found that the day is discovered to commit other violations that are threatened by the same sanctions; Or

c. Notary gets 3 (three) temporary dismissal sanctions for a period of 12 (twelve) months.

The obligation referred to in Article 10 letter $(a)$ pursuant to Article 7 paragraph (2) is in the case of notarized termination of his position, the notary Central Supervisory Assembly shall establishes an obligations which must be fulfilled by the notary during the period of temporary termination. Obligations referred to Article 8 Regulation of the Minister of Justice and Human Rights(Permenkumham) is the notary must submit a notarized protocol to another notary as a protocol holder. This is in line with the provisions of Article 67 paragraph (2) of regulation of the Minister of Justice and Human rights number 25 of 2014 on the terms and procedures of adoption, displacement,

\footnotetext{
${ }^{1}$ Salim HS, Peraturan Jabatan Notaris, Sinar Grafika, Jakarta, 2018, page165.

${ }^{2}$ An interview with I Made Puspa Wijaya Kusuma, a member of the regional supervisory assembly from the Government, on 26 February 2020, at the Regional office of the Ministry of Justice and Human rights of West Nusa Tenggara province, at 09.00 WITA

${ }^{3}$ Interview with Notary M. Ali, SH., MKn, on 28 January 2020 at the office of notary M. Ali, SH., MKn at 11.00 WITA

${ }^{4}$ An interview with I Made Puspa Wijaya Kusuma, a member of the regional supervisory assembly from the Government, on 26 February 2020, at the Regional office of the Ministry of Justice and Human rights of West Nusa Tenggara province, at 09.00 WITA.
} 
termination, and extension of the notary term stating that:

The notarized notary and other notaries as protocol holders shall submit the protocol handover in the presence of the MPD within a period of no more than 14 (fourteen) days since the decision of the termination of temporary acceptance.

Based on this, in Article 10 letter (a) is mentioned that the notary can be dismissed with disrespect from the post if it does not carry out the obligation in which the obligation in question is not to submit a notary protocol to another notary as a protocol holder when the notary in question will undergo a temporary termination from his position. This is still causing confusion because in Article 12 letter (d) is mentioned that the notary can be dismissed with disrespect from his post if the notary committed a severe violation of obligations and a notarized ban.

Not to mention the arrangement of the indicator or the benchmark of severe violations of the notary public in The Notary Public Law-P is different from the provisions governing the indicator of severe violations of The Land Deed Official In the appendix of the Ministerial Regulation of agrarian and spatial/Head of National Land Agency of the Republic of Indonesia number 2 year 2018 about the construction and supervision of The Land Deed Official very clearly mentioned the indicator of heavy violations of The Land Deed Official against its position obligations or prohibitions so that The Land Deed Official can be dismissed in disrespect from his office.

It is understood that The Land Deed Official can be dismissed in disrespect from its position when committing a serious breach of The Land Deed Official's obligations or prohibitions. But in this case, unlike the arrangement in The Notary Public Law or The Notary Public Law-P which has not arrange clearly on the indicator of heavy violations of the obligation and prohibition of notary, indicators of severe violations of the obligation or ban of The Land Deed Official has been very clearly regulated in the appendix of the Ministerial Regulation of agrarian and spatial/Head of national Land Agency of the Republic of Indonesia number 2, 2018.

As explained above by analyzing the law of notary Office and its implementation rules, notary Code of ethics, government regulation on The Land Deed Official, as well as the opinions of some sources, in this case indicators of severe violations of the obligations and notaries based on The Notary Public Law can be categorized as:

1. Notary does not act trustworthy, honest, careful, independent, immoral and keep the interests of the parties in legal action;

2. Notary does not make any deed in the form of deed Minuta and save it as part of a notary protocol;

3. Notary does not attach letters and documents as well as fingerprints of the the appearer Deed minuta;

4. Notary Public does not issue a Grosse deed, a copy of the deed, or an excerpt of deed based on the deed minuta;

5. Notary Public does not keep all things confidential about the deed he made and any information obtained in order to make the deed in accordance with the oath/pledge of office, unless the law determines otherwise;

6. The notary public does not submit a list of deed as referred to in letter (i) or a list of nil that pertains to Wills to the center of Wills in the Ministry that conducts government affairs in the field of law within 5 (five) days in the first week of each subsequent month;

7. Notary Public does not read the deed in front of the appearer by being attended by at least 2 (two) witnesses, or 4 (four) special witnesses to the creation of a will private, and signed at that time also by the appearer, witnesses, and notary;

8. Notary Public positions outside of office;

9. Notaries concurrently as civil servants, state officials, advocates, leaders or officers of state-owned enterprises, district-owned enterprises or private enterprises, and concurrently serving as Land Deed Official and/or Class II Auction Officials outside the place of notary public;

Indicators of severe violations of the obligations and notaries need to be set forth in the notary Law and notary Code of ethics as there is no specific arrangement in the law. Severe violations are explained only to the extent of not carrying out the obligation and violate the notary public, but from some of the obligations and prohibitions owned by the notary there has not been a clear arrangement governing the obligations and prohibitions which can be categorized as a severe breach so that the notary in question can be dismissed in disrespect of his office. Based on the indicator of severe violations of obligations and notaries should be given classification to no longer elicit the multitasking and confusion, so it is clear and can provide legal certainty for all parties.

2. Implementation of Legal Sanctions on Notary Public with A Serious Breach of Obligations and Prohibitions The fact of sanction as a compulsion is based on the law also to give awareness to the party that violates that an action has been done is not accordance with the rules of law. This is to return the infringing party to conduct in accordance with the applicable law, and to maintain the balance of the rule of law. Sanctions that is aimed at notary is also a form of awareness, that the notary in the task of his office has violated the provisions on the execution of the duties of the notary Office as stated in The Notary Public Law, and to return the notary action in carrying out the duties of office in order to comply with The Notary Public Law and notary Code of ethics. ${ }^{1}$

\footnotetext{
${ }^{1}$ Sjaifurrahman dan Habib Adjie, Aspek Pertanggungjawaban Notaris dalam Pembuatan Akta, CV. Mandar Maju, 2011, page. 194.
} 
Administrative sanctions can be imposed against a notary who violates the Article on obligations and prohibitions in The Notary Public Law which include Article 7 paragraph (1), Article 16, Article 17, Article 19, Article 32, Article 37, Article 54, Article 58, Article 59 The Notary Public Law.

Civil sanctions against notaries that violate the Articles on obligations and prohibitions in The Notary Public Law are among them Article 16 paragraph (1) J, Article 16 paragraph (1) Letter M, Article 16 paragraph (7), Article 38, Article 39 and Article 40, Article 44, Article 48, Article 49, Article 50 and Article 51. Civil sanction as described above clauses is reimbursement, indemnity and interest is a result that notary will receive from the Appearers claim if the deed has only the power of proof as private deed. Reimbursement, indemnity or interest can be sued against notary, but must first be able to explain the limitations or articles which have been violated by the notary public and shall be based on a legal relationship between the notary and the parties.

In addition to sanctions already listed in the The Notary Public Law, other sanctions that can be imposed on the notary is the sanction of the notary Code of Ethics (hereinafter called KEN). Notary Public may be subject to sanctioned code for violating the prohibition as stipulated in Article 4 of the notary code of conduct. Sanctions that may be imposed against members of the Indonesian Notary Association (INI), who commit violations of the code of ethics may be strikes, warnings, suspensions (temporary dismissal) of the membership of the Association and Onzetting (termination) of membership of the Association. ${ }^{1}$

A notary in comitting violation can actually be subject to administrative or civil litigation or a notary Code of Ethics conduct, but then withdrawn or qualified as a criminal offence committed by the notary. These qualifications relate to several aspects such as:

a. Does not warrant the certainty of the day, date, month, year and time of facing;

b. Who is the person facing a notary public;

c. Not excluding signatures facing;

d. Found a copy of deed not in accordance with deed minuta;

e. There is a copy of the deed, without being made a deed; and F. Minuta deed is not fully signed, but a copy of the minuta deed is issued.

These aspects are the only limitations that can be proved as the basis for administrative sanctions and civil sanction against notary public. However, on the other hand, such constraints are made the basis for a notarized notary with a notary public to have made false letters or falsify the Deed (section 263, 264 and 266 of the Criminal Code) with qualifications as a criminal offence committed by the notary. In addition to the allegation of making false letters or faking deeds, notary Public can also be charged with the alleged conduct of criminal acts of fraud as stipulated in Article 372 and 374 of the Criminal Code, money laundering crimes stipulated in Law number 8 of 2010 concerning prevention and Eradication of money laundering, or criminal acts giving false remarks under the oath stipulated in Article 242 of the Criminal Code.

Therefore, a notarized EAS can be done with the limitations of: ${ }^{2}$

1. There is a legal action from notary to the formal aspect of the deed deliberately, full of consciousness and ininteractivity and planned, that the deed made before the notary or by notary together (agreed) to be used as the basis for the conduct of a criminal act;

2. There is a legal action from the notary in making a deed before or by a notary who, if measured based on the The Notary Public Law, does not comply/contradict the The Notary Public Law;

3. Notary action is not appropriate according to the authorities in this case the supervisory assembly of notary. The allotment of criminal sanctions against notary can be done along the limits as mentioned above is violated, meaning that in addition to fulfilling the formulation of the breach in The Notary Public Law and the code of Ethics of the Department of notary also must fulfill the formulation of such a term in the Criminal Code.

\section{CONCLUSION}

Indicator of severe violations as referred to in Article 12 letter d The Notary Public Law and explanation is not fulfill obligations and violate the prohibition of notary office. The notary obligation stipulated in Article 16 of The Notary Public Law-P which if not fulfilled can be categorized as a severe violation among them is a notarized unacting, honest, careful, independent, immoral and safeguard the interests of the parties in conducting legal action, notary does not make a deed in the form of Deed Minuta and save it as part of a notary protocol, notarized not to attach letters and documents as well as fingerprints of the complainers in deed, notaries do not issue grosse deed, copies of the deed, or deed excerpts based on a deed, notary No and any information obtained for the creation of the deed, notary does not submit a list of deeds relating to the will to the center of Wills in the Ministry of Government conducting Legal affairs within 5 (five) days of the first week of the following month, the notary is not reading the deed in front of the appearer by being attended by at least 2 (two) witnesses, or 4 (four) special

\footnotetext{
${ }^{1}$ Abdul Ghofur Anshori, Lembaga Kenotariatan Indonesia, Perspektif Hukum dan Etika, UII Press, 2009, Yogyakarta, page. 70-71.

${ }^{2}$ Sjaifurrahman dan Habib Adjie, Op.Cit., page. 208.
} 
witnesses to the creation private deed and signed at that time also by the appearer, witnesses, and notary. A notarized prohibition as stipulated in Article 17 of The Notary Public Law-P that if violated can be categorized as a severe violation, i.e. a notary public, running a position outside of office, a notary as a civil servant, state officer, advocate, leader or officer of a state-owned enterprise, a regional-owned business entity or a private business entity, and concurrently serving as land deed official and/or class II auction office outside the notary public.

The application of legal sanctions against notaries that commit severeviolations of the obligation and the notarial ban are administrative sanctions, civil sanctions, notary code sanctions and criminal sanctions. For the application of civil sanction and criminal sanctions against a notary, it depends on the person who feels harmed, whether to take the civil line by filing a lawsuit or taking a criminal pathway by submitting a report in which both the lawsuit and the report are submitted to the local district Court as a result of the deed committed by the notary.

\section{SUGGESTION}

Severe violations are explained only to the extent of not carrying out the obligation and violate the notary public, but from some of the obligations and prohibitions owned by the notary there is no clear arrangement that governs the obligations and prohibitions which can be categorized as a severe violation so that the notary in question can be dismissed in disrespect of his office. Based on the indicator of severe violations of obligations and notaries should be given classification to no longer cause interpretations problems and confusion, so it is clear and can provide legal certainty for all parties.

Notary is expected to maintain the attitude and professional nature, more careful and thorough and have good faith in the making of the deed so as to avoid matters relating to legal sanctions. In addition, notary is expected to remain in his role of serving the community in the creation of the deed based on moral and ethical without violating the prevailing regulations.

\section{REFFERENCES}

Salim H.S, 2015, Teknik Pembuatan Akta Satu Konsep Teoritis, Kewenangan Notaris, Bentuk dan Minuta Akta, PT. Raja Grafindo Persada, Jakarta 2018, Peraturan Jabatan Notaris, Sinar Grafika, Jakarta

Sjaifurrahman dan Habib Adjie, 2011, Aspek Pertanggungjawaban Notaris dalam Pembuatan Akta, CV. Mandar Maju, Bandung

Abdul Ghofur Anshori, 2009, Lembaga Kenotariatan Indonesia, Perspektif Hukum dan Etika, UII Press, Yogyakarta

Indonesia, law Number 30 of 2004 about notary tenure, LN number 117 TLN number 4432

Indonesia, law Number 2 of 2014 concerning amendment to law number 30 of 2004 about notary tenure, TLN No. 4491

Regulation of the Minister of Law and Human rights No. 25 of 2014 on terms and procedures of appointment, displacement, termination, and extension of notary term

Indonesia, regulation of the Minister of Law and Human rights No. 61 of 2016 on procedures for the procedure to rationalise the administrative sanctions on notary 